\title{
Blood scandal raises spectre of Dreyfus case
}

Paris. Science is on a collision course with the French legal system over the handling of investigations into the contamination of blood with HIV in the mid-1980s. Last week, the affair took a new twist with the decision to add François Gros, the former director of the Institut Pasteur, to the list of those indicted.

But the affair is turning into one of the biggest legal controversies since the historic 'Dreyfus affair' a century ago, when Alfred Dreyfus, an innocent Jewish army officer was convicted of treason. As in the Dreyfus case, France is deeply divided, this time between those who believe that the contamination is the collective responsibility of the state and those who see it as a crime perpetrated by a small number of individuals.

The divisions have sharpened following last month's indictment on charges of 'collusion in poisoning' of Laurent Fabius, the prime minister at the time, Edmond Hervé, the secretary of state for health, and Georgina Dufoix, the minister for social affairs.

Contributing to the controversy is the feeling that the truth of the matter remains elusive, despite repeated investigations and criminal proceedings. Indeed, Simone Veil, the health minister, declared last week that "a general explanation of the entire transfusion system in 1985 " is still needed.

The French affair involves three separate issues. Were haemophiliacs given HIV-infected clotting factors when heat-inactivated alternatives were available? Was routine screening postponed to await a French test when a US test was already available? Were blood donations from prisons stepped up despite warnings about collecting from highrisk populations?

Axel Kahn, of the Cochin Institute of Molecular Genetics in Paris, says that one point of general concern is that the judiciary is conceding to the demands of a "vindic- tive" public. "Guilt is being presumed," he says. The formula being used is "how dare you say you are innocent, that you did your best, when 1,000 are dead", says Kahn. "It's an extraordinary perversion of justice."

Contempt for the law "is the old French disease", said one lawyer, while another suggests that "to exorcise the big fear of our time, we need guilty parties". Jean Bernard, president of the National Blood Transfusion Centre (CNTS) board until December 1984 and former president of the national bioethics advisory committee, has also said that the courts should have called foreign scientists as witnesses, "because the same things happened everywhere".

Indeed, the Conseil d'Etat has fixed the state's responsibility "as of November 1983" on the grounds that the threat of HIV was then "established by the scientific community". But many argue that consensus was reached only after Robert Gallo published his rediscovery of HIV in April 1984.

More contentious is the Conseil's assertion that the efficacy of heat-inactivation was accepted by 13 October 1984. It based this on a recommendation - incorrectly attributed to the 'World Haemophilia Organization" - that "the value of the protection [of heated products] against the AIDS virus should be taken as established".

In fact, the recommendation, made by the US National Haemophilia Foundation, said only that clinicians "using coagulationfactor concentrates should strongly consider changing to heat-treated products with the understanding that the protection against AIDS is yet to be proven". Worryingly, both errors match previous ones made by a French journalist, suggesting that the Conseil did not consult the original documents.

Many of the investigations into the affair also have potential conflicts of interest. A 1991 inquiry was carried out by the General
Inspectorate for Social Affairs (IGAS), for example. But in a report published in May 1985, IGAS had endorsed the commercial approach of Michel Garretta, then head of CNTS. Running CNTS, it said, requires not skills in "research and teaching", but in "organization, methods and the promotion of technologies". Moreover, the word 'AIDS' does not appear once in the report.

Michel Lucas, the author of the 1991 IGAS report on the blood affair, also later supervised an IGAS report on the collection of blood in prisons that exonerated the ministry of justice. But Lucas had been copresident of the Prisons Administration when it issued a decree in January 1984 increasing the collection of blood from prisons.

Prison blood accounted for almost a third of all contamination in 1985 , which partly explains why 1,300 people were contaminated through whole-blood transfusions in France, compared with 70 in the United Kingdom, where routine screening was introduced two months later than in France.

But the report claims, for example, that the Prisons Administration was unaware of a 1983 circular warning against collecting blood from high-risk populations, although the warnings were widely covered in the media. Health officials also allege that the ministry of justice demanded the deletion of an explicit reference to prisons in a 1985 revision of this circular; the ministry is said to have denied the allegation.

The report claims that instructions from the Prisons Administration in 1984 calling for an "increase in the frequency of collections... and in the number of donor detainees", was not intended to mean stepping up donations.

The question of whether officials delayed introducing routine screening using a US test because they were waiting for a French test is also more complex than is commonly portrayed. For one thing, it took place against the background of the bitter US/French dispute over the origin of the AIDS test.

And although the French were clearly protectionist, this seems to have been widely known, if not widely endorsed. In March 1985, the daily medical newspaper $L e$ Quotidien du Medecin ran a headline "The War of the Tests", and the Quotidien de Paris (21 July 1985) reported that "for obvious reasons of national interest" the government prefers the Pasteur test.

Moreover, for at least part of 1985 , there was widespread dissent about the wisdom of introducing routine screening (see Nature 367, 673; 1994). And although the US test had been approved by the US Food and Drug Adminstration (FDA) in early 1985, FDA documents support French arguments that there remained genuine concerns about the quality of the test.

Declan Butler 